\title{
Medicinal Value of Croton macrostachyus and Solanum incanum against Causative Agent of Foodborne Diseases
}

\author{
Tagesu Abdisa, DVM* \\ Department of Veterinary Medicine, College of Veterinary Medicine, Jimma University, Jimma, Ethiopia
}

"Corresponding author

Tagesu Abdisa, DVM

Department of Veterinary Medicine, College of Veterinary Medicine, Jimma University, Jimma, Ethiopia; Tel. +25 I93368I I407; E-mail: abdisatagesu@gmail.com

\section{Article information}

Received: August 23 ${ }^{\text {rd }}$, 2019; Revised: October $3^{\text {rd }}, 2019$; Accepted: November 14 ${ }^{\text {th }}, 2019$; Published: November $22^{\text {nd }}, 2019$

\section{Cite this article}

Abdisa T. Medicinal value of Croton Macrostachyus and Solanum Incanum in treatment of foodborne diseases. Vet Med Open J. 2019; 4(2): 57-68. doi: I0.17I40/VMOJ-4-137

\section{ABSTRACT}

Foodborne diseases are a public health threat which causes a large economic impact across the worldwide. Escherichia coli (E. coli), Listeria monocytogenes (L. monocytogenes), Salmonella species (S. species), Staphylococcus aureus (S. aureus) and many more other organisms are the leading causes of foodborne illness and death in the world. Increment of antibiotic resistance exhibited by the actions of microbial infectious agents has led to screening of several medicinal plants for their potential antimicrobial activity. Therefore, the aim of this paper is to review on the medicinal value of Croton macrostachyus (C. macrostachyus) and Solanum incanum (S. incanum) against causative agents of foodborne disease. Antimicrobial compounds of medicinal plants differ from antibiotics as they have fewer side effects, better patient tolerance, relatively less expensive, acceptance due to a long history of use and being renewable in nature. There are so many medicinal plants used to treat foodborne diseases which associated with gastroenteritis in humans and animals, among plants $S$. incanum and C. macrostachyus are the common for treatment of foodborne diseases associated with diarrhea. $S$. incanum has different bioactive substances which have medicinal importance against skin diseases, abdominal pains, fever, stomachaches and indigestion, treatment of dandruff, wounds, sore throat, angina, ear inflammation, liver disorders, wart and ringworm and treatment of cow driosis, dermatophilosis, foot rot, pasteurellosis, black leg, fasciolosis and snake bite. Bioactive compounds which present in $S$. incanum are including alkaloids, steroids, saponins, tannins, glycosides, flavonoid and terpenoids. C. macrostachyus is medicinal plant which have bioactive compounds including terpenoids, alkaloids, flavonoids, lignoids, proanthcyanidins, sesquiterpenoids and lupeol, saponnins, resins, crotepeoxide. C. macrostachyus have medicinal value in treatment of malaria, rabies, gonorrhea, wound, diarrhea, hepatitis, jaundice, abdominal pain, cancer, toothache, pneumonia, typhoidand gastrointestinal disorder. Which is also used as abortifacient and uterotonic to expel retained placenta. Therefore, S. incanum and C. macrostachyus have different medicinal value against foodborne disease and drug-resistance infectious agents. However, an advanced study have not been conducted on the extract of pure bioactive compounds and toxicity analysis. Therefore, further studies should have to be conducted to extract pure compounds from these medicinal plants for pharmaceutics industry.

\section{Keywords}

Bioactive substance; Drug resistance; Food borne disease; Infectious agent; Medicinal plants.

\section{INTRODUCTION}

$\mathrm{F}$ oodborne diseases are a public health threat which causes a large economic impact across the worldwide. It can be caused by pathogens including bacteria, viruses and parasitic organisms. ${ }^{1}$ Foodborne pathogens including Escherichia coli (E. coli), Listeria monocytogenes (L. monocytogenes), S. species, Staphylococcus aureus (S. aure$u s)$ and many more other organisms are the leading causes of foodborne illness and death in the world. ${ }^{2}$ Foodborne zoonotic diseases often occur due to the consumption of contaminated food-stuffs especially from animal products such as meat and milk. ${ }^{3,4}$

Diarrheagenic Escherichia coli (DEC) strains is one of the causative agent of foodborne diseases which leading causes of diarrheal illnesses throughout the world both in humans and animals. ${ }^{5,6}$ Gastroenteritis due to foodborne disease is one of the most common illnesses in Ethiopia, and it is a leading cause of death among people of all ages in the country. ${ }^{7}$ The occurrence of E. coli in foods of animal origin in Ethiopia is arguably high due to many reasons like illegal slaughtering of animals in open fields, un- 
hygienic slaughter practices in the abattoirs, and the risk of disease is high because of a widespread tradition of raw meat consumption. ${ }^{8,9}$ DEC contamination is usually associated with contaminated water and food, their presence reflects fecal contamination of both human and animal's origin. ${ }^{10}$

S. aureus is an opportunistic foodborne gram positive pathogen which causes many human and animal diseases. ${ }^{11} S$. aureus causes an infection in animals and humans which including inflammations of bone, meningitis, septicemia and rashes, mastitis (inflammation of mammary gland in bovine) and inflammation of lower part of the foot in poultry. ${ }^{12,13} S$. aureus is an important pathogen both in community acquired and healthcare associated infections due to its fast growing resistance to antibiotics. In particular, methicillin resistant $S$. aureus presents major infection control problems and threats globally. ${ }^{14}$

Antimicrobial resistance in bacterial pathogens is a worldwide challenge associated with high morbidity and mortality. Multidrug-resistant patterns in gram-positive and negative bacteria have resulted in difficult to treat with conventional antimicrobials. Broad spectrum antibiotics are liberally and mostly unnecessarily used and result in emergence of resistance bacteria. ${ }^{15}$ The emergence of resistant infections caused by most bacteria has led to mortality and morbidity and there is an urgent need to find solutions to combat bacterial resistance. ${ }^{16}$ The effectiveness of currently available antibiotics is decreasing due to the increasing number of resistant strains causing infections; this is due to excessive use of antimicrobial, incorrect antimicrobial dosage and unregulated access to drugs. ${ }^{17}$ The reservoir of resistant bacteria in food animals implies a potential risk for transfer of resistant bacteria, or resistance genes, from food animals to humans. ${ }^{18,19}$

The increasing antibiotic resistance exhibited by pathogenic microbial infectious agents has led to the screening of several medicinal plants for their potential antimicrobial activity. ${ }^{20}$ Medicinal plant has great role in care of primary health of humans and animals due to its biological and medicinal activities, high safety margins and ability to overcome drug resistance action of pathogens. ${ }^{21,22}$ Medicinal plants are an important source of traditional drugs, modern medicines, folk medicines, nutraceuticals, pharmaceutical intermediates and entities for synthetic drugs since plant extracts contain many medicinal metabolites such as alkaloids, glycosides, terpenoids, flavonoids and lignins. ${ }^{23}$ Antimicrobial compounds of medicinal plants differ from antibiotics as they have fewer side effects, better patient tolerance, relatively less expensive, acceptance due to long history of use and being renewable in nature. ${ }^{24}$ Ethnoveterinary practice to animal health care is as old as the domestication of various livestock species. ${ }^{25}$ There are so many medicinal plants used to treat foodborne diseases which associated with gastroenteritis in humans and animals, among plants Solanum incanum ( $S$. incanum) and Croton macrostachyus (C. macrostachyus) are the common for treatment of foodborne diseases associated with diarrhea. ${ }^{26}$

C. macrostachyus have different phytochemical which act as antidiarrheal, antimicrobial, anticonvulsant and sedative, anthel- mintic, antidiabetic, anti-inflammatory, antileishmanial, antioxidant, antiplasmodial, larvicidal and antifungal activity. The secondary bioactive compounds which have pharmaceutical activities are including alkaloids, amino acids, anthraquinones, carbohydrates, cardiac glycosides, coumarins, essential oil, fatty acids, flavonoids, phenolic compounds, phlobatannins, polyphenols, phytosteroides, saponins, sterols, tannins, terpenoids, unsaturated sterol, vitamin C, and withanoides. ${ }^{27-29}$ The bioactive compound tannin is found in S. incanum have antiseptic and vasoconstrictor affects, and also have the ability to decrease diarrhea via forming protective layers of the mucous membranes. But, not only tannin, and also astringent phenolic compounds, triterpenoids and saponins also have an antidiarrheal effect. ${ }^{30}$

Fruit extracts of S. incanum exhibited potent antibacterial effect while leaf extracts showed antimicrobial activity against the $E$. coli, S. pyogenes, $S$. aureus, and $P$. aeruginosa. Therefore, the main objective of this paper is to review on the medicinal value of $C$. macrostachyus and $S$. incanum against causative agents of foodborne diseases.

\section{MEDICINAL PLANTS AND PATHOGENIC BACTERIA}

\section{Study of Medicinal Plant}

Medicinal plants are the sources of bioactive compounds which used mainly for medicinal purposes to tackling different diseases of animals and humans especially in developing countries. ${ }^{31}$ The clinical efficacy of many existing antibiotics is being threatened by the emergence of multidrug-resistant pathogen. ${ }^{32,33}$ Medicinal plants have been widely used all over the world and formed the integral part of basic health care in many countries including Ethiopia. Modern veterinary medicine are not well-developed in most of the countries and it is estimated that the traditional remedies are sometimes the only source of therapeutics for human population and animal. ${ }^{34}$

Ethiopia is well-known with having tremendous medicinal plants which has been used for treatment of livestock and human ailments, but medicinal values of plant is not well-documented which impedes widespread use, evaluation and validation. In recent time, many young people are lack of indigenous knowledge of medicinal plant, this raised from limitation of transferring indigenous knowledge of this medicinal plants. ${ }^{35,36}$ Application practices of medicinal plant range from administration of the roots, barks, stems, leaves and seeds to the use of extracts, infusions, powders and decoction from the plant. ${ }^{37,38}$ The innovational approach between plants and healthy is launching new generation of multi-component of botanic drugs, dietary supplements and plant produced recombinant proteins..$^{31,39}$

Ethnoveterinary medicine is the scientific term for traditional animal health care, encompasses the knowledge, skills, methods, practices, and beliefs about animal health care found among the members of a community. The knowledge base differs not only from region to region but also among and within communities. It has been developed through trial and error and deliberate 
experimentation. $^{40}$

The plant-based human and livestock health care persists and remains as the main alternative treatment for different ailments in Ethiopia, largely due to shortage of pharmaceutical products, prohibitive distance of the health service stations, unaffordable prices by small holder farmers and pastoralists for conventional drugs, emergence and re-emergence of certain diseases and appearance of drug resistant microbes and/or helminthes. ${ }^{41}$ Studying of medicinal plant have great role in innovating the novel drug or alternative antimicrobial components from different plant parts. World Health Organization (WHO) estimates show that about $80 \%$ of African people rely on folklore herbal medicine for their primary health care due to scarcity or exorbitant prices of modern medicines. It is believed that herbal medicines exhibit less toxic and cost effective that the synthetic counterpart modern one. ${ }^{42}$ Research investigation of S. incanum and C. macrostachyus have been showed the medicinal value of these plants which including in treatment of gastrointestinal infections, toothaches, dermatitis, wound, malaria and dandruff. ${ }^{43}$

Solanum incanum: $S$. incanum have different names in different languages such as; Hiddii loonii (Afan Oromo), Embouy (Amharic) and Sodom/bitter apple (English)) as indicated in Figure 1(B). The name $S$. incanum is derived from Latin words, 'Solamen' meaning "relief" indicating the narcotic effects of the plant and 'incanum' meaning "white". ${ }^{44}$ It is a native African shrub which belongs to Solanaceae family and also grows in many regions of Africa, Middle East and Far East Asia. ${ }^{45-47}$ S. incanum is a delicate perennial plant often cultivated as an annual crop. It grows 1-3 $\mathrm{m}$ high with simple leaves, ovate, elliptic, $2.5-12 \mathrm{~cm}$ long and $2.5-8 \mathrm{~cm}$ wide. The fruit is fleshy, less than $3 \mathrm{~cm}$ in diameter on wild plants but much larger in cultivated forms. Botanically the fruit is classified as a berry and contains numerous small, soft seeds which are edible, but are bitter because they contain an insignificant amount of nicotinoid alkaloids. Flowers are in clusters along the branches corolla pale to deep blue, purple, occasionally white. Fruit is spherical, green, often striped or mottled with white, turning yellow to orange brown when ripe. $S$. incanum is the bushy herbal plant, native to north and north eastern Africa including Ethiopia. It found at forest edges and in bush land, grass land from sea level-up to $2500 \mathrm{~m}$ altitude. ${ }^{48}$

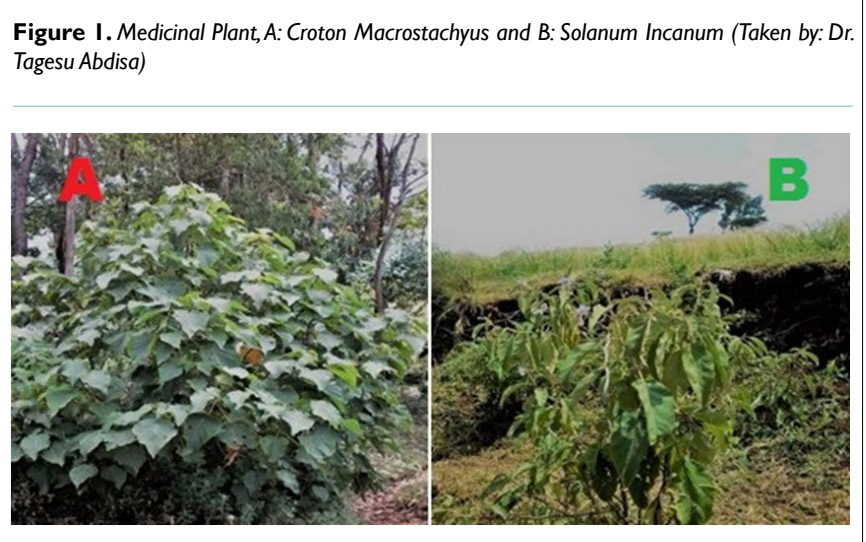

Phytochemical constituent of S. incanum: The bioactive substances which exist in fruit of $S$. incanum includes: alkaloids, steroids, cardiac glycosides, saponins, flavonoids, tannins, oxalates and cyanogenic glycosides, but anthraquinones is absent. ${ }^{49}$ The leaves of $S$. incanum contains alkaloid, steroid, glycosides, flavonoid, saponin, tannins, triterpenes and cardiac glycosides. Root of S. incanum consist of spirostanol saponin, four known saponins, indioside D, dioscin, protodioscin, methylrotodioscin and steroid glycoalkaloid solamargine. Aerial part (the part above soil) consists of two steroidal glycosidal alkaloids, solasonine and solamarginine and nonsteroidal components like three phenylalkanoic acids, benzyl-Ob-d-xylopyranosy-b-D-glucopyranoside, flavonoids, chlorogenic acid, adenosine and new compound kaempferol. ${ }^{50-52}$

The medicinal value of $\boldsymbol{S}$. incanum: $S$. incanum is a medicinal plant widely employed around the world as antifungal, antiulcerogenic, antinociceptive, antipyrectic, anti-spasmolytic, orexic, hypoglycemic, antimicrobial, antischistosomal, laxative, antimicrobial, hemorrhoids and snake bites. ${ }^{48,53} S$. incanum have various medicinal importance, it was employed in eastern and southern Africa for the treatment of skin diseases, general infections, abdominal pains, fever, stomachaches and indigestion, treatment of dandruff (fruit), wounds, sore throat, angina, ear inflammation, liver disorders, wart, ringworm. ${ }^{54,55}$ In Oromia region the fruit of $S$. incanum is the main medicinal plant used for the treatment of cowdriosis, dermatophilosis skin lesion, foot rot and pasteurellosis and also the root decoction of $S$. incanum is used to treat black legs, fasciolosis and snake bite. ${ }^{56}$

As one research reported ${ }^{57}$ that $S$. incanum have the antimicrobial activities against gram positive and gram negative bacteria such as: $S$. aureus, Bacillus subtilis, P. aeruginosa, E. coli, Salmonella paratyphi and Vibrio cholera. Fruit of $S$. incanum is used for control of tick infestation in Ethiopia. ${ }^{8} \mathrm{~S}$. incanum also used in pain relieve in toothache and cure poison of snake bites as well as used in curdling milk or making cheese, leather tanning and soap making due to its alkaloid constituent. ${ }^{59,60}$

The extraction of $S$. incanum have great role in treatment of cancer, which containing the active ingredient solamargine, can induce apoptosis via up regulation of tumor necrosis factor expression and activation of the mitochondrial apoptosis pathway, and also have therapeutic effect in treatment of patient with actinic keratosis. ${ }^{61,62}$ The alkaloid also rapidly induced membrane blebbing which could not be prevented by chelating either the intracellular or extracellular calcium ions though it was inhibited by some polyethylene glycols. It also disrupted the cytoplasmic actin and microtubules. ${ }^{63}$

The S. incanum have antitypanosomal compound which is steroidal alkaloids derivatives such as cilistol-A, solasonine, solamargine and chaconine; this compounds act as antitypanosomal activity against Typanosoma cruzi and Typanosoma brucei and also have anti-leishmaniasis, $S$. incanum antiprotozoal effect has been reported for the first time against $P$. falciparum, $L$. infantum, T. brucei and T. cruqi. ${ }^{64,65}$ 
C. macrostachyus: C. macrostachyus is commonly known as; rush foil (English), Bakkaniisa (Afan Oromo) and Bisana (Amharic) as indicated in Figure 1(A). It belongs to the Euphorbiacea with 300 genera and 8,000-10,000 species and most abundant plant in the tropics. ${ }^{66,67}$ It is native to Ethiopia, Eretria, Kenya, Tanzania, Uganda and Nigeria which is a medium-sized deciduous tree of East Africa particularly wide spread between 200-2500. In mountainous forests and savannah of the tropical regions and ever green bush land areas that receive between 700-701, $200 \mathrm{~mm}$ rainfall annually. ${ }^{68-70}$ The name of Croton comes from a Greek word 'Kroton' which means ticks, because of the seeds' resemblance to ticks, the specific name "macrostachyus" is a contraction of two words, the Greek word "macro" meaning large and "stachyus" relating to the spike, hence, a species characterized by large spikes. ${ }^{71}$ C. macrostachyus is regarded as a multipurpose tree by subsistence farmers in Ethiopia, Kenya, and Tanzania and the species has potential in playing an important role in the primary healthcare. The bark, fruits, leaves, roots, and seeds of $C$. macrostachyus are reported to possess diverse medicinal properties and $C$. macrostachyus is used as herbal medicine for at least 61 human and 20 animal diseases and ailments. In the distribution area there is a high degree of medicinal use consensus for bleeding, blood clotting, cancer, constipation, diarrhea, epilepsy, malaria, pneumonia, purgative, ringworm, skin diseases or infections, stomach ache, typhoid, worm expulsion, and wounds. ${ }^{29,72}$

Phytochemical constituent of $\boldsymbol{C}$. macrostachyus: The genus Croton is rich in terpenoids (diterpenoids and triterpenoids), alkaloids, flavonoids, lignoids, proanthcyanidins and volatile oils containing monoterpenoids, sesquiterpenoids and some shikimate-derived compounds. Previous studies showed the existence of crotin (a chalcone), lupeol (a triperpene), crotepoxide (a cyclohexane diepoxide), proteins, fatty acids, saponins, resins and alkaloids. ${ }^{29,73}$ The activity of $C$. macrostachyus stem bark extracts is comparable to studies where antiplasmodial activity has been related to a range of several classes of secondary plant metabolites including alkaloids and sesquiterpenes, triterpenes, flavonoids, inonoids, and quassinoids. $^{73}$

Medicinal value of $\mathbf{C}$. macrostachyus: Traditionally $C$. macrostachyus used for treatment of malaria, rabies, gonorrhea, wound, diarrhea, hepatitis, jaundice, scabies, toothache, abdominal pain, cancer, typhoid, pneumonia and gastrointestinal disorders and as ethnoveterinary medicine. ${ }^{74-76}$ Pharmacological studies on C. macrostachyus indicate that it has a wide range of pharmacological activities such as anthelmintic, antibacterial, antimycobacterial, antidiarrheal, antifungal, anticonvulsant and sedative, antidiabetic, anti-inflammatory, antileishmanial, antioxidant, antiplasmodial, and larvicidal effects. ${ }^{29}$ The leaves and shoots of C. macrostachyus are used to treat fever and oedema and also mashed leaves used for treatment of hemorrhoids. Moreover, the maceration of $C$. macrostachyus stem bark is used as abortifacient and uterotonic to expel retained placenta. ${ }^{77}$

C. macrostachyus have the activities of against diarrhea; traditional healers in Ethiopia use a wide range of medicinal plants with antidiarrheal properties. ${ }^{28}$ The chemical constituent in the $C$. macrostachyus, Terpenoids such as abietic acid and steroids like phytosterols have been showed to inhibit production of prostaglandin
E2 which have a crucial role in stimulation of intestinal secretion, therefore it has antidiarrheal activities. ${ }^{78,79}$

\section{Study of Pathogenic Bacteria}

Escherichia coli and its infection: Escherichia coli a gram negative non-spore forming facultative anaerobic rod. Genus E. coli belongs to the bacterial group formally called "coliforms" which are member of the "enterics" known as Enterobacteriaceae family. ${ }^{80}$ The strain of E. coli are motile because they have flagella arranged in peritrichous, but those lack of flagella are non-motile. ${ }^{81}$ E. coli is a catalase positive, oxidase negative, lactose fermenter, coccobacillus gram negative non spore forming rod shaped bacteria. ${ }^{82}$ E. coli requires the ability to adapt to variations or extreme changes in temperature, $\mathrm{pH}$, and osmolarity conditions commonly encountered in nature. For example, the exopolysaccharide (EPS) production of E. coli is associated with heat and acid tolerance, and the alteration of lipid composition in membranes is induced by heat stress. ${ }^{83} \mathrm{E}$. coli can survive for a long time in water, especially at cold temperatures. Water trough sediments contaminated with bovine feces can serve as a long-term (>8-months) reservoir of E. coli, and the surviving bacteria in contaminated troughs is a source of infection. ${ }^{84}$

E. coli are one of the major etiological agents of calf diarrhea with severe lethal outcome and major damage to the livestock industry worldwide, consequently highly mortality rate in calves under three weeks old and up to 3-months-old has been reported. ${ }^{85,86}$ Diarrhea in animals especially in young cattle is one of the frequently encountered clinical syndromes, it causes economic losses from mortality and morbidity, treatment costs and time spent on care as well as chronic ill-thrift nature of calf diarrhea. ${ }^{87}$

DEC can be divided into six pathogens includes; Enterotoxigenic E. coli (ETEC), Eenteropathogenic E. coli (EPEC), Enterohemorrhagic E. coli (EHE), Enteroinvesive E. coli (EIEC), Diffusely adherent E. coli (DAEC) and Vero or shiga like toxin producing E. coli. ${ }^{88,89}$ The food types most commonly associated with outbreaks of food poisoning due to E. coli are mostly of bovine origin, in particular, beef and beef burgers and unpasteurized milk. ${ }^{90,91}$ However, it has been increasingly recognized that fresh vegetables and fruits other than beef or beef-product can be the sources of Shiga toxin-producing E. coli (STEC) infection. ${ }^{92-94}$

DEC is the most common pathogenic to human which cause bloody diarrhea and HUS or TTP but, it has no any clinical disease except diarrhea in cattle and other animals. ${ }^{95,96}$ The human can be infected with E. coli through consumption of contaminated food of bovine origins, fecal contaminated of food products and direct contact with infected animals. ${ }^{97} \mathrm{E}$. coli are part of the intestinal microflora of health animals and humans which can carry genes that allow them to produce toxins known as Vero toxins or Shiga-like toxins. Verotoxigenic E. coli (VTEC) are not pathogenic to ruminants, but they cause serious diseases in humans worldwide, including diarrhea, hemorrhagic colitis, hemolytic-uremic syndrome, and sometimes death. ${ }^{98}$ Shiga toxin producing E. coli is 
ubiquitous food and water borne pathogens inhabiting different animals, wildlife and humans. ${ }^{99-101}$

Shiga toxin producing E. coli are associated with dysentery in calves. As it was reported that, E. coli O157:H7 was isolated from fecal samples of calves. ${ }^{102}$ The pathogenic E. coli is carried in the intestinal tract and excreted in the feces, and also present on the skin which can be transferred to carcass during evisceration. The contaminate during slaughter may cause the spread of E. coli to carcass and the human can be infected after consumption. ${ }^{103}$

After ingestion of E. coli, the bacteria bind to intestinal mucosa and begin releasing Shiga toxin. The produced toxins disrupt protein synthesis in the epithelial cells lining intestinal mucosa, small vessels of the intestine, kidney and brain resulting in thrombotic microangiopathy. E. coli attaches to the microvilli of intestinal epithelial cells and initiates colonization and establishes intimate attachment which is responsible for the translocation of a variety of effectors which alter the structure and function of host cells. ${ }^{104}$ Vero toxin producing E. coli are widespread in animals but ruminants thought to be the natural reservoir. E. coli colonizes the terminal colon of cattle and can be shed in very large numbers by herd mates known as "super shedders". Feces containing these organisms act as a source of contamination for a variety of foods and the environment. ${ }^{105}$

Staphylococcus aureus and its infection: $S$. aureus is a facultative anaerobic which belongs to the family of Staphylococcoceae. It is gram positive coagulase and catalase positive and non-spore forming non-motile which have paired cocci in grape like bunch structural shape. ${ }^{106} S$. aureus causes mastitis in milking herds, and occasionally purulent dermatitis in their milkers. ${ }^{107} \mathrm{~S}$. aureus is the most commonly affected part of the body due to infection is the skin. The skin infections are including small benign boils, folliculate, impetigo, cellulitis and invasive soft tissue infections. ${ }^{108}$

S. aureus is an important cause of hospital and community acquires infections which frequently resistance to many different classes of antimicrobial drugs. It was first described as hospital acquired methicillin-resistant S. aureus (MRSA) in 1961 as nosocomial infections. Later on the pathogen was observed in healthy humans without hospitalization and it terms community acquired MRSA. ${ }^{109,110}$ Livestock-associated MRSA was first associated with human disease in 2003, when a MRSA clone associated with a reservoir in pigs and cattle was isolated from a human. ${ }^{111}$ MRSA has been found in horse and livestock. MRSA can be transmitted from livestock to care takers, during milking and treating of animals. ${ }^{112-114} S$. aureus is unique in its ability to clot plasma during coagulase test which distinguish Staphylococcus epidemidicus and S. hyicus (coagulase negative). S. aureus are tolerant to high concentration of salt and show resistance to heat. $S$. aureus is grown on mannitol salt agar with golden orange to yellowish colonies which distinguish it from $S$. epidermidis and S. byicus. ${ }^{15,116}$

\section{Antimicrobial Resistance}

Antimicrobial resistance is one of the most common disastrous factor to global public health. Bacterial resistance to antibiotics has increased rapidly within recent years which have led to the increase in the incidence of infectious diseases caused by those multi-drug resistant bacteria. Infections caused by multi-drug resistant bacteria involve higher morbidity, mortality, and a burden to health care systems. The common cause for antimicrobial resistance effect of bacteria is drug residue, due to contamination of meat products with antibiotic residues when the human consume meat with drug residue, then the appearance of resistant bacteria may occur. ${ }^{117-119}$ The main mechanisms of microorganism for antimicrobial resistance are antibiotic inactivation, target modification, changes in permeability and altering metabolic pathway, decreased antibiotic penetration, $\beta$ lactamase production and efflux pumps. ${ }^{120}$

The antimicrobial drug resistance can be caused by intrinsic and acquired methods. Intrinsic mechanisms are those specified by naturally occurring genes found on the bacterial chromosome. Intrinsic mechanism is due to the presence of outer cell membrane in gram negative bacteria and expression of efflux pumps. The acquired resistance mechanism is due to chromosomal mutation and horizontal transfer of mobile genetic elements from other bacteria in the environment via carrying the resistance gene including plasmids, transposon and integrons. The genetic element can be transferred from one bacterium to other through conjunction (cellto-cell contact between elements), transduction (bacteriophage facilitated transfer of genetic information) and transformation (uptake of free deoxyribonucleic acid (DNA) from the environment. ${ }^{71,121-123}$ Gram negative bacteria possesses high permeability barrier for numerous antibiotic molecules. Their periplasmic space contains enzymes which are capable of breaking down foreign molecules, so gram negatives are less susceptible to plant extraction than gram positive bacteria. ${ }^{124}$

\section{Drug Extraction and Phytochemical Bioactive Compounds}

Crude extraction of medicinal plant: The plant extract drugs are new interest as antiseptics and antimicrobial agents in medicine which have safer biologically active compounds with acceptable therapeutic index for development of novel drugs. ${ }^{125,126}$ Plant extracts have more active target sites against drug resistant pathogens. ${ }^{127}$ Plant extraction is the procedure of the separation of medicinal active portions of plant from inactive component part of plants, which undergoes by using solvents diffuse into the solid plant material and solubilize compounds with similar polarity. ${ }^{128}$ Plant extraction can be carried out in different steps including collection of plant parts, drying, size reduction (grinding into pieces), extraction by mixing with solvents, filtration, concentration by rota vapor, drying and reconstitution. The quality and quantity of crude extraction may be influenced by several factors including plant part, solvent, procedure and ration of solvent to plant. ${ }^{129,130}$

The concept of solubility 'like dissolve like' which mean polar solvent (water, ethanol, methanol) extracts out polar substances and non-polar solvents extracts out non-polar solvents (petroleum ether, acetone and chloroform), this mechanism is depending of functional groups of solvents. ${ }^{131}$ There are so many methods for crude extraction from plant including, maceration, 
soxhlet apparatus, infusion. Maceration is one of the extraction techniques which have been used in wine making and medicinal plant research investigation. It involves soaking plant materials in a container with solvent and allowed to stand at room temperature for 3-7-days with frequent agitation. ${ }^{129}$

Phytochemical secondary bioactive compounds: Plant produces many secondary metabolites which constitute an important source of antimicrobial, pesticides and pharmaceutical drugs and also medicinal plants are best source to obtain novel drugs. ${ }^{132,133}$ Phytochemicals can be classified as primary and secondary compounds. Chlorophyll, proteins and common sugars are included in primary constituents and secondary compounds have terpenoid, alkaloids and phenolic compounds. ${ }^{134}$ Terpenoids exhibit various important pharmacological activities i.e., anti-inflammatory, anti-cancer, antimalarial, inhibition of cholesterol synthesis, anti-viral and anti-bacterial activities. Terpenoids are very important in attracting useful mites and consume the herbivorous insects. Alkaloids are used as anaesthetic agents and are found in medicinal plants. ${ }^{135}$

Glycosides moieties including saponins, cardiac glycosides and flavonoids are used to inhibit tumor growth, serve to protect against gastrointestinal infection which caused by pathogens those that cause enteric infection. ${ }^{136,137}$ Secondary metabolites of medicinal plants have different mechanism of actions against bacteria agents. The mechanism can be through inhibition of bacterial enzymes, affecting cell division, bacterial membrane disruption and affecting virulence genes. The mode action of alkaloid is through inhibition of FtsZ (Flamenting temperature sensitive mutant Z) assembly and its GTPase activities which causes cell elongation without cell division. Protein FtsZ have greater role in bacterial cell division which have homolog of the eukaryotic tubulin, then this protein has the affinity to bind with alkaloid which inhibit cell division. ${ }^{138}$

The hydrophobic nature of essential oils (non-polar bio active compounds) disrupted metabolic activities and energy production line of the bacterial cells. It affected on the plasma membrane which makes bacterial cells more permeable to other bioactive compounds. ${ }^{139}$ The mechanism of phytochemical secondary metabolites act with forming complexes with bacterial cell and inhibit cell activities. Flavonoids can for complexes with bacterial cell proteins and interfere with cell activities in the process of bacterial adhesion. Tannin and flavonoids have an antibacterial effect which can bind with proteins and inhibiting cell protein synthesis. ${ }^{140}$

\section{CONCLUSION AND RECOMMENDATIONS}

Foodborne diseases and drug resistance infectious agents are the most common disaster against the health of animals and humans throughout the world. Bacterial resistance to antibiotics has increased rapidly which have led to increase in the incidence of infectious diseases caused by those multi-drug resistant bacteria. Infections caused by multi-drug resistant bacteria involve higher morbidity, mortality, and a burden to health care systems. Moreover, foodborne disease which caused by E.coli and S. aureus is the most common in developing countries especially in young animals and children. However, medicinal plants are the natural resources which have so many bioactive secondary metabolites against pathogenic organisms. Bioactive compounds have different mechanisms against infectious agents through affecting cell division, enzyme inhibition of bacteria, bacterial membrane disruption, affecting virulence genes and disruption of protein synthesis of bacteria. Therefore, $S$. incanaum and C. macrostachyus have different medicinal value against foodborne disease and drug resistance infectious agents. These medicinal plants have various novel bioactive compounds, although further research studies have not been conducted on the extract of pure bioactive compounds and toxicity analysis. Therefore, the further study should have to be conducted to extract pure compounds rather than crude extract from these medicinal plants for pharmaceutics industry.

\section{REFERENCES}

1. Abd-alfatah AA, Ishak CY, Ayoub SMH. Antimicrobial activity of four medicinal plants used by Sudanese traditional medicinal plants. Journal of Forest Products Industries. 2013; 2(1): 29-33.

2. Abdalla I. Leaves value of Solanum incanum at Khartoum North-Sudan. International Journal of Engineering Science and Innovative Technology. 2015; 4(1): 25-28.

3. Abebe H, Gebre T, Haile A. Phytochemical investigation on the roots of Solanum incanum, Hadiya Zone, Ethiopia. Journal of $\mathrm{Me}$ dicinal Plants. 2014; 2(2): 83-93.

4. Abreu Miranda M, Tiossi R, Rodrigues $\mathrm{K}$, et al. In vitro leishmanicidal and cytotoxic activities of the glycoalkaloids from Solanum incanum (Solanaceae) fruits. Chem Biodivers. 2013; 10(4): 642648. doi: 10.1002/cbdv.201200063

5. Abubeker H. A Study on ethnoveterinary knowledge and practices in lowlands of Borana pastoral system. [dissertation]. Faculty of Veterinary Medicine of Addis Ababa. 2003.

6. Ahmad I, Beg A. Antimicrobial and phytochemical studies on 45 Indian medicinal plants against multi-drug resistant human pathogens. J Ethnopharmacol. 2001; 74 (2):113-123. doi: 10.1016/s03788741(00)00335-4

7. Aklilu E, Zunita Z, Hassan L, Chen HC. Phenotypic and genotypic characterization of methicillin-resistant Staphylococcus aureus (MRSA) isolated from dogs and cats at University Veterinary Hospital, University Putra Malaysia. Trop Biomed. 2010; 27(3): 483-492.

8. Alekshun MN, Levy SB. Molecular mechanisms of antibacterial multidrug resistance. Cell. 2007; 128: 1037-1050. doi: 10.1016/j. cell.2007.03.004

9. Anteneh B, Zemede A, Sebsebe D, Negussie F. Medicinal plants potential and use by pastoral and agro-pastoral communities in Erer valley of Babile wereda, Eastern Ethiopia. J Ethnobiol Ethnomed. 2012; 8: 42. doi: 10.1186/1746-4269-8-42 
10. Anwar S. Pharmacological investigation of Solanum incanum against P. Falciparum, L. infantum, T. cruzi and T. brucei: A role of antioxidant effect and clinical overview. Biomedical and Pharmacology Journal. 2018; 11(2): 653-660. doi: 10.13005/bpj/1418

11. Armand-Lefevre L, Ruimy R, Andremont A. Clonal comparison of Staphylococcus aureus isolates from healthy pig farmers, human controls, and pigs. Emerg Infect Dis. 2005; 11(5): 711-714. doi: $10.3201 /$ eid1105.040866

12. Assefa A, Bihon A. A systematic review and meta-analysis of prevalence of Escherichia coli in foods of animal origin in Ethiopia. Heliyon. 2018; 4(8): e00716. doi: 10.1016/j.heliyon.2018.e00716

13. Assefa A, Urga K, Guta M, et al. Spasmolytic activity of the aqueous root extract of Solanum incanum, Solanaceae. Ethiopian Journal of Biological Sciences. 2006; 5(2): 137-146. doi: 10.4314/ejbs. v5i2.39032

14. Atnafie B, Paulos D, Abera M, et al. Occurrence of Escherichia coli O157: H7 in cattle faeces and contamination of carcass and various contact surfaces in abattoir and butcher shops of Hawassa, Ethiopia. BMC Microbiol. 2017; 17(1): 24. doi: 10.1186/s12866017-0938-1

15. Auta, R. Nutritional and chemical evaluation of Solanum incanum (Bitter garden egg). International Journal of Tropical Medicine and Public Health Supplement. 2011; 1: 96-107.

16. Awad AB, Toczek J, Fink CS. Phytosterols decrease prostaglandin release in cultured P388D1/MAB macrophages. Prostaglandins Leukot Essent Fatty Acids. 2004; 70(6): 511-520. doi: 10.1016/j.plefa.2003.11.005

17. Ayana Z, Yohannis M, Abera Z. Food-borne bacterial diseases in Ethiopia. Academic Journal of Nutrition. 2015; 4(1): 62-76. doi: 10.5829/idosi.ajn.2015.4.1.95168

18. Azwanida NN. A review on the extraction methods use in medicinal plants, principle, strength and limitation. Med Aromat Plants. 2015; 4(3): 1-6. doi: 10.4172/2167-0412.1000196

19. Balaji N, Chakravarthi P. Ethnoveterinary Practices in India-A Review. Vet World.2010; 3(12). doi: 10.5455/vetworld.2010.549-551

20. Banatvala N, Griffin P, Greene K, et al. The United States national prospective haemolytic uremic syndrome study: microbiologic, serologic, clinical, and epidemiologic findings. I Infect Dis. 2001; 183(7): 1063-1070. doi: 10.1086/319269

21. Bazeley K. Investigation of diarrhea in the neonatal calf. Clinical Practice. 2003; 25(3): 152-159. doi: 10.1136/inpract.25.3.152

22. Bekele D, Asfaw Z, Petros B, Tekie H. Ethnobotanical study of plants used for protection against insect bite and for the treatment of livestock health problems in rural areas of Akaki District, Eastern Shewa, Ethiopia. Topclass Journal of Herbal Medicine. 2012;
1(2): 40-52.

23. Bern MJ, Sturbaum CW, Karayalcin SS, Berschneider HM, Wachsman JT, Powell DW. Immune system control of rat and rabbit colonic electrolyte transport. Role of prostaglandins and enteric nervous system. J Clin Invest. 1989; 83(6): 1810-1820. doi: 10.1172/JCI114086

24. Berry P. Floristics and molecular phylogeny of a giant genusCroton (Euphorbiaceae). 2000.

25. Bobbarala V, Katikala P, Naidu K, Penumajji S. Antifungal activity of selected plant extracts against phytopathogenic fungi Aspergillus Niger F2723. Indian Journal of Science Technology. 2009; 2(4): 87-90.

26. Boberek JM, Stach J, Good L. Genetic evidence for inhibition of bacterial division protein FtsZ by berberine. PLoS One. 2010; 5: e13745. doi: 10.1371/journal.pone.0013745

27. Britto S, Senthilkumar S. Antibacterial activity of Solanum incanum L. leaf extracts. Asian Journal Microbiology Biotechnology Environmental Science. 2001; 3(1): 65-66.

28. Burt S. Essential oils: their antibacterial properties and potential applications in foods: A review. Int J Food Microbiol. 2004; 94: 223-253. doi: 10.1016/j.ijfoodmicro.2004.03.022

29. Carlet J, Jarlier V, Harbarth S, Voss A, Goossens H, Pittet D. Ready for a world without antibiotics? The pensieres antibiotic resistance calls to action. Antimicrob Resist Infect Control. 2012; 1: 11. doi: 10.1186/2047-2994-1-11

30. Centers for Disease Control and Prevention (CDC). Multistate outbreaks of shiga toxin-producing Escherichia coli O26 infections linked to chipotle mexican grill restaurants. 2015. Web site. https://www.cdc.gov/ecoli/2015/o26-11-15/index.html. Accessed August 22, 2019.

31. Cowan MM. Plant products as antimicrobial agents. Clin Microbiol Rev. 1999; 12: 564-582. doi: 10.1128/CMR.12.4.564

32. Cox G, Wright GD. Intrinsic antibiotic resistance: Mechanisms, origins, challenges and solutions. Int J Med Microbiol. 2013; 303: 287 292. doi: 10.1016/j.ijmm.2013.02.009

33. Cyrus W, Daniel G, Nanyingi M, Njonge F, Mbaria J. Antibacterial and cytotoxic activity of Kenyan medicinal plants. Mem Inst Oswaldo Cruq. 2008; 103(7): 650-652. doi: 10.1590/s007402762008000700004

34. Darnton N, Turner L, Rojevsky S, Berg HC. On torque and tumbling in swimming Escherichia coli. J Bacteriol. 2007; 189(5): 1756-1764. doi: 10.1128/JB.01501-06

35. Dastmalchi S, Ayremlou N. Characterization of Shiga toxin producing Escherichia coli (STEC) in faeces of healthy and diarrheic 
calves in Urmia region, Iran. Iran J Microbiol. 2012; 4: 63-69.

36. Degu A, Engidawork E, Shibeshi W. Evaluation of the antidiarrheal activity of the leaf extract of Croton macrostachyus Hocsht. ex Del.(Euphorbiaceae) in mice model. BMC Complement Altern Med. 2016; 16(1): 379. doi: 10.1186/s12906-016-1357-9

37. Ekor M. The growing use of herbal medicines: Issues relating to adverse reactions and challenges in monitoring safety. Front Pharmacol. 2014; 4: 177. doi: 10.3389/fphar.2013.00177

38. Endalkachew A, Negesse M. In vitro antibacterial activity of Rumex nervosus, Plantago lanceolata, Solanum incanum and Lepidium sativum against selected bacterial pathogens of human and animals. Ethiopian Veterinary Journal. 2016; 20(2): 119-131. doi: 10.4314/evj. v20i2.9

39. Molla AE, Sfaw, ZA, Kelbessa E, Nagappan R. Ethnobotanical study of traditional medicinal plants in and around Fiche District, Central Ethiopia. Current Research Journal of Biological Sciences. 2014; 6(4): 154-167.

40. Eshetu GR, Dejene TA, Telila LB, Bekele DF. Ethnoveterinary medicinal plants: Preparation and application methods by traditional healers in selected districts of southern Ethiopia. Vet World. 2015; 8(5): 674 -684. doi: 10.14202/vetworld.2015.674-684

41. Espenhain LE. Epidemiology and Surveillance of Three Diarrheagenic Escherichia coli in Denmark between 2000-2012. [master's thesis]. København, Denmark: University of Copenhagen; 2013.

42. Farrokh C, Jordan K, Auvray F, et al. Review of Shiga-toxinproducing Escherichia coli (STEC) and their significance in dairy production. Int J Food Microbiol. 2013; 162(2): 190-212. doi: 10.1016/j. ijfoodmicro.2012.08.008

43. Fotadar U, Zaveloff P, Terracio L. Growth of Escherichia coli at elevated temperatures. J Basic Microbiol. 2005; 45(5): 403-404. doi: 10.1002/jobm.200410542

44. Frieri M, Kumar K, Boutin A. Antibiotic resistance. J Infect Public Health. 2017; 10(4): 369-378. doi: 10.1016/j.jiph.2016.08.007

45. Friese A, Schulz J, Zimmermann K, et al. Occurrence of livestock-associated methicillin-resistant Staphylococcus aureus in Turkey and broiler barns and contamination of air and soil surfaces in their vicinity. Appl Environ Microbiol. 2013; 79(8): 2759-2766. doi: 10.1128/AEM.03939-12

46. Fullas F. Ethiopian medicinal plants in veterinary healthcare: A mini-review. Ethiopian e-Journal for Research and Innovation Foresight. 2010; 2(1): 48-58.

47. Garcia A, Fox J, Besser T. Zoonotic enterohemorrhagic Escherichia coli: A one health perspective. ILAR J. 2010; 51(3): 221-232. doi: 10.1093/ilar.51.3.221
48. Springer-Verlag US . The Gammaproteobacteria. In: George G, Brenner DJ, Krieg NR, Staley JT, eds. Bergey's Manual ${ }^{\circledR}$ of Systematic Bacteriology. $2^{\text {nd }}$ ed. New York, USA: Springer Publisher; 2005: 1108. doi: 10.1007/0-387-29298-5

49. Ghosal M, Mandal P. Phytochemical screening and antioxidant activities of two selected 'BIHI'fruits used as vegetables in Darjeeling Himalaya. International Journal of Pharmacy and Pharmaceutical Sciences. 2012; 4(2): 567-574.

50. Giday M, Asfaw Z, Woldu Z. Medicinal plants of the Meinit ethnic group of Ethiopia: An ethnobotanical study. J Ethnopharmacol. 2009; 124(3): 513-521. doi: 10.1016/j.jep.2009.05.009

51. Gomes TAT, Elias WP, Scaletsky ICA, et al. Diarrheagenic E. coli. Braz J Microbiol. 2016; 47: 3-30.

52. Grinberg A, Hittman A, Leyland M, Rogers L, Le Quesne B. Epidemiological and molecular evidence of a monophyletic infection with Staphylococcus aureus causing a purulent dermatitis in a dairy farmer and multiple cases of mastitis in his cows. Epidemiol Infect. 2004; 132(3): 507-513. doi: 10.1017/s0950268804002079

53. Habib F, ah Rind R, Bhutto AL, et al. Morphological and cultural characterization of $S$. aureus isolated from different animal species. J App Environ Biol Sci. 2015; 5(2):15-26.

54. Handa SS, Khanuja SPS, Longo G, Rakesh DD. Extraction technologies for medicinal and aromatic plants. 1st ed. Web site https://www.unido.org/sites/default/files/2009-10/Extraction_ technologies_for_medicinal_and_aromatic_plants_0.pdf. Accessed August 22, 2019.

55. Harris LG, Foster SJ, Richards RG. An introduction to S. aureus, and techniques for Identifying and quantifying $S$. Aureus Adhesions in relation to Adhesion to biomass Terials: Review. European Cells and Materials. 2002; 4: 39-60. doi: 10.22203/eCM.v004a04

56. Hashish EA, El Damaty HM, Tartor YH, Abdelaal AM. Epidemiological study of diarrheagenic escherichia coli virulence genes in newborn calves. Pak Vet J. 2016; 36(1): 54-58.

57. Jaeger P, Hepper F. A review of the genus Solanum in Africa. Solanaceae Biology and Systematics. New York, USA: Columbia University Press; 1986; 41-55.

58. Heuer O, Jensen V, Hammerum A. Antimicrobial drug consumption in companion animals. Emerg Infect Dis. 2005; 11(2): 344345. doi: 10.3201 / eid1102.040827

59. Huie CW. A review of modern sample-preparation techniques for the extraction and analysis of medicinal plants. Anal Bioanal Chem. 2002; 373(1-2): 23-30. doi: 10.1007/s00216-002-1265-3

60. Huijsdens XW, Van Dijke BJ, Spalburg E, et al. Community-acquired MRSA and pig-farming. Ann Clin Microbiol Antimicrob. 2006; 5(1): 26. doi: 10.1186/1476-0711-5-26 
61. Hussein H, Lake S, Ringkob T. Cattle as a reservoir of shigalike toxin-producing Escherichia coli including O157:H7 pre-and post-harvest control measures to assure beef safety. The Professional Animal Scientist. 2001; 17(2): 1-16. doi: 10.15232/S10807446(15)31561-8

62. Indhumathi T, Mohandass S. Efficacy of Ethanolic extract of Solanum incanum fruit extract for its antimicrobial activity. International Journal of Current Microbioliology Applied Science. 2014; 3(6): 939949.

63. Jaeger P. Systematic studies in the genus Solanum in Africa. [dissertation]. Birmingham, UK. University of Birmingham. 1985.

64. Jeong KC, Hiki O, Kang MY, Park D, Kaspar CW. Prevalent and persistent Escherichia coli $\mathrm{O} 157: \mathrm{H} 7$ strains on farms are selected by bovine passage. Vet Microbiol. 2013; 162(2-4): 912-920. doi: 10.1016/j.vetmic.2012.11.034

65. Kabir SML. Effect of probiotics on broiler meat quality. African Journal of Biotechnology. 2009; 8(15): 3623-3627.

66. Kapingu MC, Guillaume D, Mbwambo ZH, Moshi MJ, Uliso FC, Mahunnah RL. Diterpenoids from the roots of Croton macrostachys. Phytochemistry. 2000; 54(8): 767-770. doi: 10.1016/s00319422(00)00166-7

67. Käppeli U, Hächler H, Giezendanner N, Beutin L, Stephan R. Human infections with non-O157 Shiga toxin-producing Escherichia coli, Switzerland, 2000-2009. Emerg Infect Dis. 2011; 17(2): 180185. doi: 10.3201/eid1702.100909

68. Karmali MA, Gannon V, Sargeant JM. Verocytotoxin-producing Escherichia coli (VTEC). Vet Microbiol. 2010; 140(3-4): 360-370. doi: 10.1016/j.vetmic.2009.04.011

69. Kaur D, Jaiswal K, Mishra S. Ethnoveterinary Practices in India: A Review. European Journal of Pharmacentical and Medical Research. 2015; 2(7): 139-143.

70. Kelly BG, Vespermann A, Bolton DJ. The role of horizontal gene transfer in the evolution of selected foodborne bacterial pathogens. Food Chem Toxicol. 2009; 47: 951-968. doi: 10.1016/j. fct.2008.02.006

71. Tolossa K, Debela E, Athanasiadou S, Tolera A, Ganga G, Houdijk J. Ethno-medicinal study of plants used for treatment of human and livestock ailments by traditional healers in South Omo, Southern Ethiopia. J Ethnobiol Ethnomed. 2013; 9(1): 32. doi: 10.1186/1746-4269-9-32

72. Khameneh B, Diab R, Ghazvini K, Bazzaz B. Breakthroughs in bacterial resistance mechanisms and the potential ways to combat them. Microb Pathog. 2016; 95: 32-42. doi: 10.1016/j.micpath.2016.02.009

73. Kiranmayi ChB, Krishnaiah N, Mallika EN. Escherichia coli
O157:H7-An emerging pathogen in foods of animal origin. Vet World. 2010; 3(8): 382-389. doi: 10.5455/vetworld.2010.382-389

74. Krishnaiah D, Sarbatly R, Bono A. Phytochemical antioxidants for health and medicine: A move towards nature. Biotechnology Molecular Biology. 2007; 1: 97-104.

75. Lai PK, Roy J. Antimicrobial and chemo preventive properties of herbs and species. Curr Med Chem. 2004; 11: 1451-1460. doi: 10.2174/0929867043365107

76. Lee JH. Methicillin (oxacillin)-resistant Staphylococcus aureus strains isolated from major food animals and their potential transmission to humans. App Environ Microbiol. 2003; 69(11): 6489-6494. doi: 10.1128/aem.69.11.6489-6494.2003

77. LeJeune JT, Besser TE, Hancock DD. Cattle water troughs as reservoirs of Escherichia coli O157. Appl Environ Microbiol. 2001; 67: 3053-3057. doi: 10.1128/AEM.67.7.3053-3057.2001

78. Linscott AJ. Food-borne illnesses. Clinical Microbiology Newsletter. 2011; 33(6): 41-45. doi: 10.1016/j.clinmicnews.2011.02.004

79. Liu LF, Liang CH, Shiu LY, Lin WL, Lin CC, Kuo KW. Action of solamargine on human lung cancer cells-enhancement of the susceptibility of cancer cells to TNFs. FEBS Lett. 2004; 577(1-2): 67-74. doi: 10.1016/j.febslet.2004.09.064

80. López-Campos G, Martínez-Suárez J, Aguado-Urda M, LópezAlonso V. Detection, identification, and analysis of foodborne pathogens. In: Microarray Detection and Characterization of Bacterial Foodborne Pathogens. Boston, MA, USA: Springer Publisher. 2012; 13-32. doi: 10.1007/978-1-4614-3250-0_2

81. Maroyi A. Ethnopharmacological uses, phytochemistry, and pharmacological properties of Croton macrostachyus Hochst. Ex Delile: A comprehensive review. Evidence-Based Complementary and Alternative Medicine. 2017; 1-17.

82. Matu EN. Solanum incanum L. Plant Resources of Tropical Africa. 2008; 2(1): 525-528.

83. McEvoy JM, Doherty AM, Sheridan JJ, et al. The prevalence and spread of Escherichia coli O157:H7 at a commercial beef abattoir. J Appl Microbiol. 2003; 95(2): 256-266. doi: 10.1046/j.13652672.2003.01981.x

84. Mechesso A, Tadese A, Tesfaye R, Tamiru W, Eguale T. Experimental evaluation of wound healing activity of Croton macrostachyus in rat. African Journal of Pharmacy and Pharmacology. 2016; 10(39): 832-838. doi: 10.5897/AJPP2015.4454

85. Merle R, Hajek P, Käsbohrer A, et al. Monitoring of antibiotic consumption in livestock: A German feasibility study. Prev Vet Med. 2012; 104(1-2): 34-43. doi: 10.1016/j.prevetmed.2011.10.013

86. Mwonjoria JK, Ngeranwa JJ, Githinji CG, Kahiga T, Kariuki 
HN, Waweru FN. Suppression of nociception by S.incanum (Lin.) Diclomethane root extract is associated anti-inflammatory activity. The Journal of Phytopharmacology and Toxicology. 2014 b; 3: 156-162.

87. Mwonjoria JK, Ngeranwa JJ, Kariuki HN, Githinji CG, Sagini MN, Wambugu SN. Ethno medicinal, phytochemical and pharmacological aspects of Sincanum (lin.). International Journal of Pharmacology and Toxicology. 2014a; 2(2): 17-20.

88. Nagy B, Fekete PZ. Enterotoxigenic Escherichia coli in veterinary medicine. Int J Med Microbiol. 2005; 295: 443-454. doi: 10.1016/j.ijmm.2005.07.003

89. Nascimento G, Locatelli J, Freitas P, Giuliana L. Antibacterial activity of plant extracts and phytochemicals on antibiotic resistant bacteria. Brazilian Journal of Microbiology. 2000; 31: 247-256.

90. Nawaz SK, Riaz S, Hasnain S. Screening for anti-methicillin resistant Staphylococcus aureus (MRSA) bacitracin producing bacteria. Afr. J. Biotechnol. 2009; 8(3): 365-368.

91. Nostro A, Germano MP, D’Angelo V, Marino A, Cannatelli MA. Extraction methods and bioautography for evaluation of medicinal plant antimicrobial activity. Lett App Microbiol. 2000; 30(5): 379-385. doi: 10.1046/j.1472-765x.2000.00731.x

92. Obey JK, Ngeiywa MM, Kiprono P, et al. Antimalarial activity of Croton macrostachyus stem bark extracts against Plasmodium berghei in Vivo. Journal of Pathogens. 2018; 2016: 5. doi: $10.1155 / 2018 / 2393854$

93. Okafor F, Sanders O, Wilson T. Epidemiological approaches to food safety. Food Protection Trends. 2011; 31(9): 560-568.

94. Okonko IO, Nkang AO, Fajobi EA, et al. Incidence of multidrug resistant (MDR) organisms in some poultry feeds sold in Calabar Metropolis, Nigeria. Electronic Journal of Environmental, $\mathrm{Ag}$ ricultural and Food Chemistry. 2010; 9(3): 514-532.

95. Oliphant CM, Eroschenko K. Antibiotic resistance, part 2: Gram-negative pathogens. JNP. 2015; 11: 79-86. doi: 10.1016/j. nurpra.2014.10.008

96. Pandey A, Tripathi S. Concept of standardization, extraction and pre phytochemical screening strategies for herbal drug. Journal of Pharmacognosy and Phytochemistry. 2014; 2(5): 115-119.

97. Papadopoulou A, Green RJ, Frazier RA. Interaction of flavonoids with bovine serum albumin: A fluorescence quenching study. J Agric Food Chem. 2005; 53(1):158-163. doi: 10.1021/jf048693g

98. Parekh J, Chanda S. In vitro antimicrobial activity and phytochemical analysis of some Indian medicinal plants. Turkey Journal of Bioliology. 2007; 31(1): 53-58.

99. Pavithra PS, Janani VS, Charumathi KH, Indumathy R, Potala S, Verma R. Antibacterial activity of plants used in Indian herbal medicine. International Journal of Green Pharmacy (IJGP). 2010; 4(1). doi: 10.4103/0973-8258.62161

100. Pennington H. Escherichia coli O157. Lancet. 2010; 376(9750): 1428-1435. doi: 10.1016/S0140-6736(10)60963-4

101. Petruzzi L, Corbo M, Sinigaglia M, Bevilacqua A. Microbial spoilage of foods: Fundamentals. In: The Microbiological Quality of Food. Sawston, Cambridge, England: Woodhead Publishing; 2017: 1-21.

102. Pexara A, Solomakos N, Govaris A. Prevalence of methicillin-resistant Staphylococcus aureus in milk and dairy products. Journal of the Hellenic Veterinary Medical Society. 2013; 64(1): 17-34. doi: 10.12681/jhvms.15449

103. Quinn P, Carter M, Markey B, Carter G. Staphylococcus species. In: Clinical Veterinary Microbiology. Missouri, USA: Mosby Publications; 2000: 118-126.

104. Rangel JM, Sparling PH, Crowe C, Griffin PM, Swerdlow DL. Epidemiology of Escherichia coli O157:H7 outbreaks, united states, 1982-2002. Emerg Infect Dis. 2005; 11(4): 603-609. doi: 10.3201/ eid1104.040739

105. Raskin I, Ribnicky DM, Komarnytsky S, et al. Plants and human health in the twenty-first century. Trends Biotechnol. 2002; 20(12): 522-531. doi: 10.1016/S0167-7799(02)02080-2

106. Redda YT, Kebede E, Cruz Cruz, Gugsa G, Awol N, Mengeste B. Potential antibacterial activity of crude extracts from aloe vera, zingiber officinale and vinca major medicinal plants. International Journals. 2014; 5(3): 202-207. doi: 10.5829/idosi.ijmr.2014.5.3.86177

107. Regassa A. The use of herbal preparations for tick control in western Ethiopia. J S Afr Vet Assoc. 2000; 71(4): 240-243. doi: 10.4102/jsava.v71i4.722

108. Salatino A, Salatino M, Negri G. Traditional uses, chemistry and pharmacology of Croton species (Euphorbiaceae). J. Bra\%: Chem. Soc. 2007; 18(1): 11-33. doi: 10.1590/S0103-50532007000100002

109. Sambo HS, Olatunde A, Kiyawa AS. Phytochemical, proximate and mineral analyses of Solanum incanum fruit. International Journal of Chemical, Material and Environmental Research. 2016; 3(1): $8-13$.

110. Scazzocchio F, Comets M, Tomassini L, Palmery M. Antibacterial activity of Hydrastis canadensis extract and it's major isolated alkaloids. Planta Med. 2001; 67: 561-563. doi: 10.1055/s2001-16493

111. Schmelzer G, Gurib-Fakim A, Arroo R, et al. Plant resources of tropical Africa: Medicinal plants 1. PROTA Foundation. 2013; 11(2).

112. Sendeku W, Alefew B, Mengiste D, et al. Antibacterial activity 
of Croton macrostachyus against some selected pathogenic bacteria. Biotechnology International. 2015; 8(1): 11-20.

113. Stepp JR. The role of weeds as sources of pharmaceuticals. J Ethnopharmacol. 2004; 92(2-3): 163-166. doi: 10.1016/j. jep.2004.03.002

114. Sun L, Zhao Y, Yuan H, Li X, Cheng A, Lou H. Solamargine, a steroidal alkaloid glycoside, induces oncosis in human K562 leukemia and squamous cell carcinoma KB cells. Cancer Chemother Pharmacol. 2011; 67(4): 813-821. doi: 10.1007/s00280-010-1387-9

115. Tane P, Tatsimo S, Connolly J. Crotomacrine, a new clerodane diterpene from the fruits of Croton macrostachyus. Tetrahedron Letters. 2004; 45: 6997-6998. doi: 10.1016/j.tetlet.2004.08.001

116. Tapsell L, Hemphill I, Cobiac L, Patch C, Sullivan D, Fenech M. Health benefits of herbs and species: The past, the present and the future. Med J Aust. 2006; 185: S4-S24.

117. Taye B, Giday M, Animut A, Seid A. Antimicrobial activity of selected plants in traditional treatment of wounds in Ethiopia. Asian Pacific Journal of Tropical Biomedical. 2011; 1: 370-375. doi: 10.1016/S2221-1691(11)60082-8

118. Teklehaymanot T, Giday M. Ethnobotanical study of medicinal plants used by people in Zegie Peninsua, Northwestern Ethiopia. J Ethnobiol Ethnomedicine. 2007; 3:12. doi: 10.1186/1746-42693-12

119. Tenover FC, Biddle JW, Lancaster MV. Increasing resistance to vancomycin and other glycopeptides in Staphylococcus aureus. Emerg Infect Dis. 2001; 7(2): 327-332. doi: 10.3201/eid0702.010237

120. Tenover FC. Mechanisms of antimicrobial resistance in bacteria. Am J Infect Control. 2006; 34(5 Suppl 1): S3-S10. doi: 10.1016/j. ajic.2006.05.219

121. Tewelde S, Ghebriel O. Phytochemical investigation and antimicrobial activities of the fruit extract of Solanum incanum grown in Eretria. Ornamental and Medicinal Plants. 2017; 1(1): 15-25.

122. Tiwari P, Kumar B, Kaur M, Kaur G, Kaur H. Phytochemical screening and extraction: A Review. Internationale Pharmaceutica Sciencia. 2011; 1: 98-106.

123. Tong SY, Davis JS, Eichenberger E, Holland TL, Fowler VG. Staphylococcus aureus infections: Epidemiology, pathophysiology, clinical manifestations, and management. Clin Microbiol Rev. 2015; 28(3): 603-661. doi: 10.1128/CMR.00134-14

124. Van Wyk B, Van Staden J. A review of ethnobotanical research in southern Africa. South African Journal of Botany. 2002; 68(1): 1-13. doi: 10.1016/S0254-6299(16)30447-1

125. VanBelkum A, Melles DC, Nouwen J, et al. Co-evolutionary aspects of human colonisation and infection by Staphylococcus aureus.
Infect Genet Evol. 2009; 9: 32-47. doi: 10.1016/j.meegid.2008.09.012

126. Verma S, Singh S. Current and future status of herbal medicines. Vet World. 2008; 1(11): 347. doi: 10.5455/vetworld.2008.347-350

127. Wadood A, Ghufran M, Jamal S, et al. Phytochemical analysis of medicinal plants occurring in local area of mardan. Biochem Anal Biochem. 2013; 2: 1-4. doi: 10.4172/2161-1009.1000144

128. Wakjira K. Seed germination physiology and nursery establishment of Croton macrostachyus Hocht. Ex Del. [master's thesis]. Addis Ababa, Ethiopia: Addis Ababa University; 2007.

129. Wakjira K, Negash L. Germination responses of croton macrostachyus (Euphorbiaceae) to various physico-chemical pre-treatment conditions. South African Journal of Botany. 2013; 87: 76-83. doi: 10.1016/j.sajb.2013.03.012

130. Gossman W, Wasey A, Salen P. Escherichia Coli (E Coli 0157 H7). FL, USA: Stat Pearls Publishing; 2018.

131. Weese JS, Archambault M, Willey BM, et al. Methicillin-resistant Staphylococcus aureus in horses and horse personnel, 2000-2002. Emerg Infect Dis. 2005; 11(3): 430-435. doi: 10.3201/eid1103.040481

132. World Health Orginization (WHO). Critically important antimicrobials for human medicine. 3rd Revision. Web site. https://apps. who.int/iris/bitstream/handle/10665/77376/9789241504485_ eng.pdf? sequence=1. Accessed August 22, 2019.

133. World Health Orginization (WHO). Escherichia coli Fact Sheet-2016. Web site. http:// www.who.int/mediacentre/factsheets/fs125/en. Accessed August 22, 2019.

134. Windeyer MC, Leslie KE, Godden SM, Hodgins DC, Lissemore KD, LeBlanc SJ. Factors associated with morbidity, mortality, and growth of dairy heifer calves up to 3 months of age. Prev Vet Med. 2014; 113: 231-240. doi: 10.1016/j.prevetmed.2013.10.019

135. Wu C, Liang C, Shiu L, et al. Solanum incanum extract (SRT100) induces human cutaneous squamous cell carcinoma apoptosis through modulating tumor necrosis factor receptor signalling pathway. J Dermatol Sci. 2011; 63(2): 83-92. doi: 10.1016/j.jdermsci.2011.04.003

136. Xia X, Meng J, McDermott P, et al. Presence and characterization of shiga toxin-producing Escherichia coli and other potentially diarrheagenic E. coli strains in retail meats. Appl Environ Microbiol. 2010; 76(6): 1709-1717. doi: 10.1128/AEM.01968-09

137. Yibralign Z. Phytochemical investigation on the stem bark of Croton macrostachyus (Bisana). [master's thesis]. Addis Ababa, Ethiopia: Addis Ababa University; 2007.

138. Yirga G. Assessment of traditional medicinal plants in Endrta District, South-eastern Tigray, Northern Ethiopia. Afr. J. Plant Sci. 2010; 4(7): 255-260. 
139. Yu S, Sheu H, Lee C. Solanum incanum extract (SR-T100) induces melanoma cell apoptosis and inhibits established lung metastasis. Oncotarget. 2017; 8(61): 103509-103517. doi: 10.18632/ oncotarget. 21508
140. Yuk HG, Marshall DL. Adaptation of Escherichia coli O157:H7 to $\mathrm{pH}$ alters membrane lipid composition, verotoxin secretion, and resistance to simulated gastric fluid acid. Appled Environmental Microbiology. 2004; 70: 3500-3505. doi: 10.1128/AEM.70.6.35003505.2004 